\title{
Preceding Rainy-Season Crops and Residue Management Practices on Growth, Yield and Economics of Succeeding Wheat under Zero-till Semi-Arid Condition
}

\author{
LP Amgain ${ }^{1 *}$, AR Sharma ${ }^{2}$ and A Shrestha ${ }^{3}$ \\ ${ }^{1}$ Associate Professor Agronomy, IAAS, Rampur Campus, India \\ ${ }^{2}$ Principal Scientist, IARI, India \\ ${ }^{3}$ Tribhuvan University, Nepal
}

*Corresponding author: LP Amgain, Tribhuvan University, Nepal.

To Cite This Article: LP Amgain, AR Sharma, A Shrestha. Preceding Rainy-Season Crops and Residue Management Practices on Growth, Yield and Economics of Succeeding Wheat under Zero-till Semi-Arid Condition. Am J Biomed Sci \& Res. 2019 - 1(2). AJBSR.MS.ID.000512. DOI: 10.34297/AJBSR.2019.01.000512

Received: January 09, 2019 | Published: January 22, 2019

\begin{abstract}
Conservation agriculture involving zero-till residue management practices with crop diversity of short-duration rainy-season crops may be more viable approach to increase the productivity and resource-use efficiency in semi-arid dryland areas. To identify suitable wheat-based cropping system an experiment was conducted with three preceding rainy-season crops pearlmillet, clusterbean and greengram along with crop residue and Leucaena twigs mulching. Both rainy- and winter-season crops were grown under zero-till along with other recommended package of practices under rainfed conditions during 2010-11 and 2011-12. Grain yield of wheat was significantly higher in 2011-12 than in 2010-11, and with crop residue than no residue. Preceding greengram resulted in significantly higher grain yield of wheat $\left(1.11 \mathrm{t} \mathrm{ha}^{-1}\right.$ in $2010-11$, and $2.49 \mathrm{t} \mathrm{ha}^{-1}$ in $2011-$ 12), followed by that after clusterbean. Greengram with crop residue recorded the highest grain yield of wheat ( $3.32 \mathrm{t}^{-1} \mathrm{a}^{-1}$ ), followed by clusterbean with Leucaena twigs (3.29 $\left.\mathrm{t} \mathrm{ha}^{-1}\right)$ and clusterbean with crop residue $\left(2.94 \mathrm{t} \mathrm{ha}^{-1}\right)$ in 2011-12. The nutrient uptake followed the same trend as grain and straw yield. The magnitude of total nutrient uptake of wheat was about 25\% more in 2011-12, than in 2010-11 due to its higher biomass production in latter year. The economic analysis exhibited the highest returns after greengram with crop residues and clusterbean with Leucaena twigs. It was concluded that wheat after greengram and clusterbean with crop residue and Leucaena twigs mulching provided higher productivity and profitability under semi-arid zero-till condition.
\end{abstract}

Keywords: Preceding crops; Residue management; Semi-arid dryland; Wheat; Zero-till

\section{Introduction}

In rainfed areas of semi-arid region, wheat is normally grown during winter after short-duration, drought-hardy diverse rainyseason crops of cereals (pearlmillet) and legumes (clusterbean and greengram). The average growth and productivity of wheat in rainfed dry lands are less than half as that of irrigated ecosystem [1]. System-oriented production technology is essential in dry land areas for maximizing the land productivity by harnessing synergies generated through various interactions in soil-crop-atmosphere continuum. Inclusion of legumes and oilseeds in the cerealbased system of these lands not only utilizes the soil nutrients and residual moisture, but also minimizes the pest hazards, and provides balanced components of proteins and fatty acids to the human beings [2]. Moreover, the inclusion of legumes in the dry land cropping system plays a vital role in improving soil fertility through addition of biologically fixed $\mathrm{N}_{2}$ [3].

Conservation tillage practices (zero-tillage + mulching + crop diversification) are a viable approach to conserve soil moisture and nutrients under dry land situations. Use of organic materials as mulch is considered poor conductor of heat that effectively moderate soil temperature, maintain soil moisture, and increase soil fertility [4] under rainfed agriculture. Several evidences of remarkable crop 
yields increment in maize-wheat system through the maintenance of appropriate vegetative cover have been documented [5-8]. Prunings of Leuceana twigs as mulch are effective for both rainy and winter-season crops [7,9]. with significant residual effects on soil fertility and productivity of subsequent crops [10,11]. Adoption of resource-conserving technologies involving zero-tillage and organic residue management is the need of the hour as a method of 'low-input agriculture' to improve productivity, resource-use efficiency and achieve sustainability in rainfed ecosystem [12]. A considerable amount of research work on conservation agriculture have been done in India and south Asia under irrigated ecosystem, but scanty information is available particularly in semi-arid drylands. Therefore, the present research work was undertaken to explore the feasibility of double cropped wheat- based system through zero-tillage and residue management under rainfed condition.

\section{Materials and Methods}

A field experiment was conducted at the Indian Agricultural Research Institute, New Delhi ( $28^{\circ} 40^{\prime} \mathrm{N}, 7^{0} 12^{\prime} \mathrm{E}, 228$ masl.) during 2010-11 and 2011-12 to study the effect of residue management and preceding rainy-season crops on growth, productivity, nutrient uptake and economics of wheat-based cropping systems. The daily meteorological data showed that there was high rainfall (954 mm) in 2010, while it was 30.6\%, less than that of 2010 in 2011 (662 $\mathrm{mm}$ ) and $10.4 \%$ less than that of average of 10 years $(739 \mathrm{~mm})$. There were more rains (10 rainy days, $85 \mathrm{~mm}$ ) during the crop season of wheat (October to April) in 2010-11, but rains were negligible (3 rainy days, $34 \mathrm{~mm}$ ) in 2011-12.

The soil of the experimental field was sandy-loam in texture, with $147.2 \mathrm{~kg}^{-1}$ alkaline $\mathrm{KMnO}_{4}$-oxidizable $\mathrm{N}, 17.0 \mathrm{~kg} \mathrm{ha}^{-1}$ $\mathrm{NaHCO}_{3}$-extractable $\mathrm{P}, 225.1 \mathrm{~kg} \mathrm{ha}^{-1} 1 \mathrm{~N} \mathrm{NH}_{4} \mathrm{OAc}$-exchangeable $\mathrm{K}$, $0.40 \%$ organic C with $7.5 \mathrm{pH}$ of soil reaction (1: 2.5 soil and water ratio). The moisture content at $-1 / 3$ and -15 atmospheric tensions was 18.8 and $6.5 \%$, respectively, with bulk density $1.55 \mathrm{Mg} \mathrm{m}^{-3}$ of surface soil layer $(0-15 \mathrm{~cm})$. Nine cropping systems involving combinations of three crops each in rainy season (pearlmillet, clusterbean and greengram) and winter season (wheat, chickpea and mustard) were grown in sequence, exclusively under zerotill rainfed condition following other recommended package of practices. Three treatments of surface cover management, viz. control (no-residue), crop residues @ $5 \mathrm{t} \mathrm{ha}^{-1}$ and Leucaena twigs @ $10 \mathrm{t} \mathrm{ha}^{-1}$ green biomass were maintained in both the seasons. The experiment was laid out in Randomized Block Design with four replications. Only three wheat-based systems out of nine diverse systems from the whole study is presented here in this research.

Wheat cv 'PBW-175' was sown on 18 October in 2010, and 11 November in 2011 with $20 \mathrm{~cm}$ row spacing with the help of Happy seeder. Crop was grown with 60:40:20 kg N-P $\mathrm{P}_{2} \mathrm{O}_{5}-\mathrm{K}_{2} \mathrm{O}$ ha-1, wherein full dose of $\mathrm{P}$ and $\mathrm{K}$ along with half $\mathrm{N}$ through DAP, MOP and urea was applied basally along with Happy seeder in rows. The remaining $\mathrm{N}$ was top-dressed twice between 30-60 DAS, coinciding with the availability of light rainfall. Soil moisture status (\%) of the profile depth in standing wheat was recorded at different growth stage in 2011-12 to see the efficiency of mulching materials in holding soil moisture. Dry matter of wheat and other growth indices like CGR, RGR and NAR were calculated from 30 DAS on wards at 30 days intervals till harvesting of wheat. The yield attributes like effective tiller $\mathrm{m}^{-2}$ was taken from fixed $1 \mathrm{~m}$ row length. Length of spike, spike weight and 1000-grain weight were taken from randomly selected ten wheat spikes. The grain and stover yields were recorded from the net plot of $10 \mathrm{~m}^{2}$ area, and grain yield was adjusted at $14 \%$ moisture. The concentration of $\mathrm{N}, \mathrm{P}$ and $\mathrm{K}$ in grain and straw of wheat was analyzed as per the standard methods [13]. and the uptake values were calculated on the basis of their dry matter yield at harvest. Economic analysis was done, and expressed as cost of cultivation, gross and net returns and net returns/ invested. The biometric data on ancillary and yield parameters were analyzed by standard statistical techniques and regression analysis for major yield attributes and grain yield was done [14].

\section{Results and Discussion}

\section{Soil moisture pattern and crop growth indices}

The crop residues held more soil moisture than the Leucaena twigs and no-residue, which resulted in higher crop growth rate under residue retention (Figure 1). The available rainfall was conserved by crop residues, which showed higher crop growth rate. Wheat is a moisture-sensitive crop, and the growth and development depend on brighter sunshine hours and favourable soil moisture.

Crop growth rate (CGR), relative growth rate (RGR), and net assimilation rate (NAR) showed that higher rates of these parameters were recorded under crop residue mulching and from 30-60 DAS (Table 1 \& 2). In 2010-11, comparatively less CGR occurred from 0-30 DAS, which might be because the crop was grown as rainfed throughout basically due to less rainfall at the time of initial planting. The rainfall received in mid-February in 2011 (49 $\mathrm{mm}$ ), and January and March in 2012 (34 mm) helped to augment the CGR. The crop residue and Leucaena twigs mulching after clusterbean and greengram resulted in relatively higher CGR, RGR and NAR than the pearlmillet without residue. This indicated that favourable soil environment could be created with the application of crop residues and preceding legume crops in wheat-based system. Several workers have found higher crop growth rates and RGR with application of crop residue and legume-based systems [15-17]. 

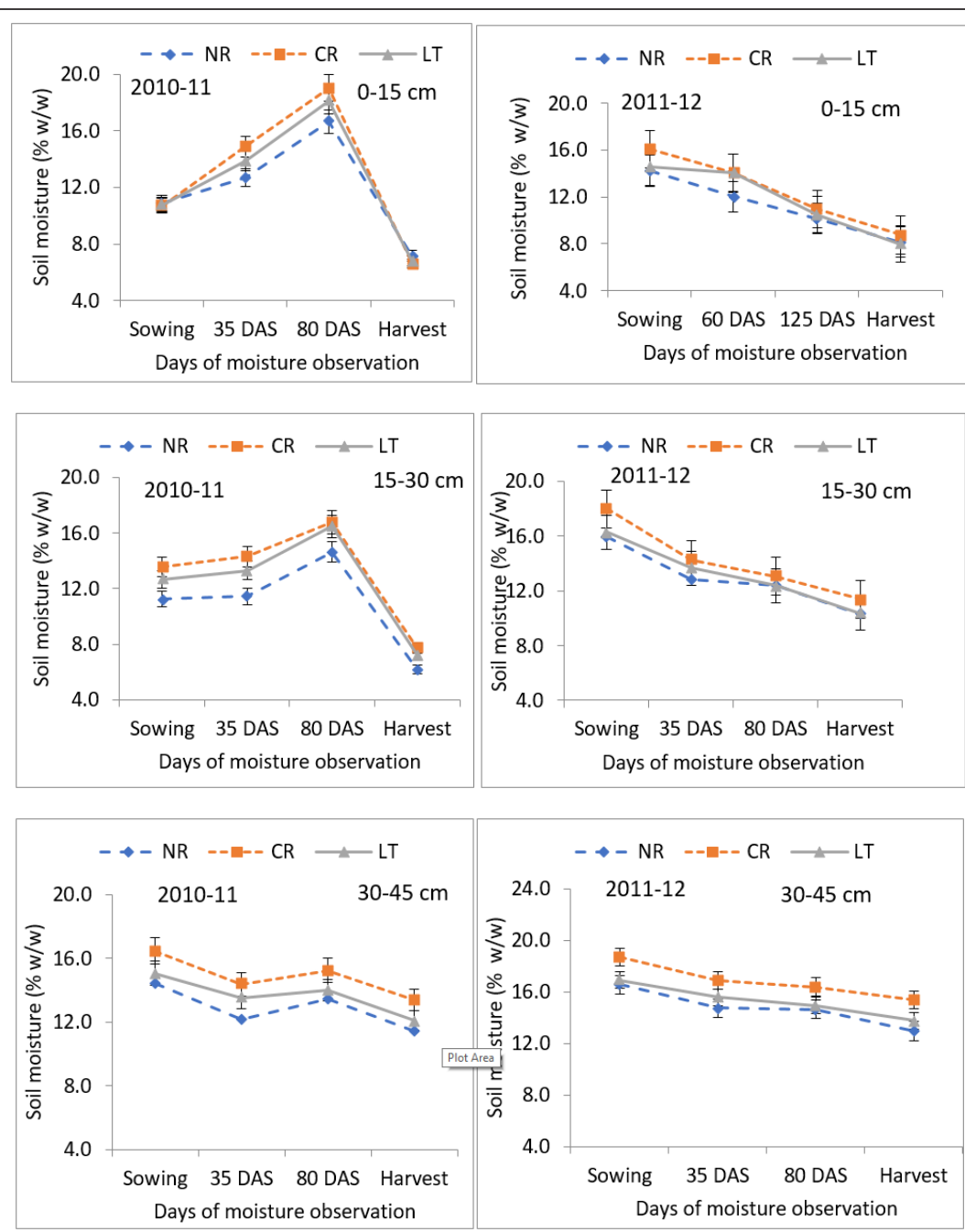

Figure 1: Profile soil moisture (\% w/w) in wheat field as influenced by residue retention practices.

\begin{tabular}{|c|c|c|c|c|c|c|c|c|c|}
\hline \multirow{2}{*}{ Treatment } & \multicolumn{4}{|c|}{ CGR $\left(\mathrm{g} \mathrm{day}^{-1} \mathrm{~m}^{-2}\right.$ ) } & \multicolumn{3}{|c|}{ RGR $\left(\mathrm{g} \mathrm{g}^{-1}\right.$ day $\left.^{-1}\right)$} & \multicolumn{2}{|c|}{ NAR (mg day ${ }^{-1} \mathrm{~m}^{-2}$ ) } \\
\hline & 0-30 DAS & 30-60 DAS & 60-90 DAS & 90-120 DAS & 30-60 DAS & 60-90 DAS & 90-120 DAS & 30-60 DAS & 60-90 DAS \\
\hline PM - NR & 1.75 & 2.73 & 1.27 & 4 & 0.057 & 0.064 & 0.056 & 0.346 & 0.771 \\
\hline PM - CR & 3.3 & 3.64 & 2.03 & 8.17 & 0.066 & 0.068 & 0.068 & 1.513 & 0.901 \\
\hline PM - LT & 2.21 & 4 & 2 & 7.56 & 0.061 & 0.069 & 0.062 & 0.516 & 0.998 \\
\hline CB - NR & 1.76 & 1.75 & 1 & 2.72 & 0.057 & 0.057 & 0.063 & 1.342 & 1.759 \\
\hline $\mathrm{CB}-\mathrm{CR}$ & 5.08 & 2.04 & 2.92 & 4.33 & 0.073 & 0.06 & 0.074 & 0.961 & 0.981 \\
\hline CB - LT & 2.68 & 3.42 & 4.19 & 7.63 & 0.064 & 0.067 & 0.066 & 0.421 & 1.5 \\
\hline GG - NR & 2.51 & 2.25 & 1.89 & 6.12 & 0.063 & 0.061 & 0.068 & 0.423 & 0.975 \\
\hline GG - CR & 4.44 & 2.6 & 3.78 & 5.92 & 0.071 & 0.063 & 0.069 & 2.982 & 1.811 \\
\hline GG - LT & 3.88 & 2.96 & 1.83 & 6.47 & 0.069 & 0.065 & 0.068 & 0.537 & 0.533 \\
\hline
\end{tabular}

Table 2: Effect of crop residue and Leucaena twigs on crop growth indices of wheat after rainy- season crops in 2011-12.

\begin{tabular}{|c|c|c|c|c|c|c|c|c|c|}
\hline \multirow{2}{*}{ Treatment } & \multicolumn{4}{|c|}{ CGR (g day ${ }^{-1} \mathrm{~m}^{-2}$ ) } & \multicolumn{3}{|c|}{ RGR $\left(\mathrm{g} \mathrm{g}^{-1}\right.$ day $\left.^{-1}\right)$} & \multicolumn{2}{|c|}{ NAR (mg day $\left.{ }^{-1} \mathrm{~m}^{-2}\right)$} \\
\hline & 0-30 DAS & 30-60 DAS & 60-90 DAS & 90-120 DAS & 30-60 DAS & 60-90 DAS & 90-120 DAS & 30-60 DAS & 60-90 DAS \\
\hline PM - NR & 3.57 & 2.61 & 1.27 & 5.77 & 0.068 & 0.063 & 0.053 & 1.254 & 0.313 \\
\hline PM - CR & 6.03 & 6.23 & 2.03 & 9.74 & 0.075 & 0.076 & 0.059 & 1.724 & 0.349 \\
\hline PM - LT & 5.85 & 7.03 & 2 & 6.6 & 0.075 & 0.077 & 0.059 & 1.864 & 0.37 \\
\hline
\end{tabular}




\begin{tabular}{|c|c|c|c|c|c|c|c|c|c|}
\hline CB - NR & 4.67 & 3.53 & 1 & 3.5 & 0.072 & 0.067 & 0.049 & 1.726 & 0.466 \\
\hline CB - CR & 6.07 & 6.25 & 2.92 & 3.18 & 0.075 & 0.076 & 0.065 & 2.069 & 0.35 \\
\hline CB - LT & 5.84 & 6.67 & 4.19 & 5.08 & 0.075 & 0.077 & 0.07 & 2.008 & 0.333 \\
\hline GG - NR & 5.65 & 3.59 & 1.89 & 4.69 & 0.074 & 0.068 & 0.058 & 1.159 & 0.469 \\
\hline GG - CR & 6.69 & 7.28 & 3.78 & 9.29 & 0.077 & 0.078 & 0.068 & 1.406 & 0.317 \\
\hline GG - LT & 5.84 & 6.9 & 2.87 & 4.88 & 0.075 & 0.077 & 0.064 & 1.598 & 0.412 \\
\hline
\end{tabular}

\section{Regression and co-relations of yield and yield attributes}

Regression analysis between yield and yield attributes of wheat exhibited significant positive correlation between wheat yield (y) with major yield attributes (x), viz. effective tillers $\mathrm{m}^{-2}$ and number of filled grains during both years, but 1000-grain weight remained significant only in 2010-11 (Figure 2).
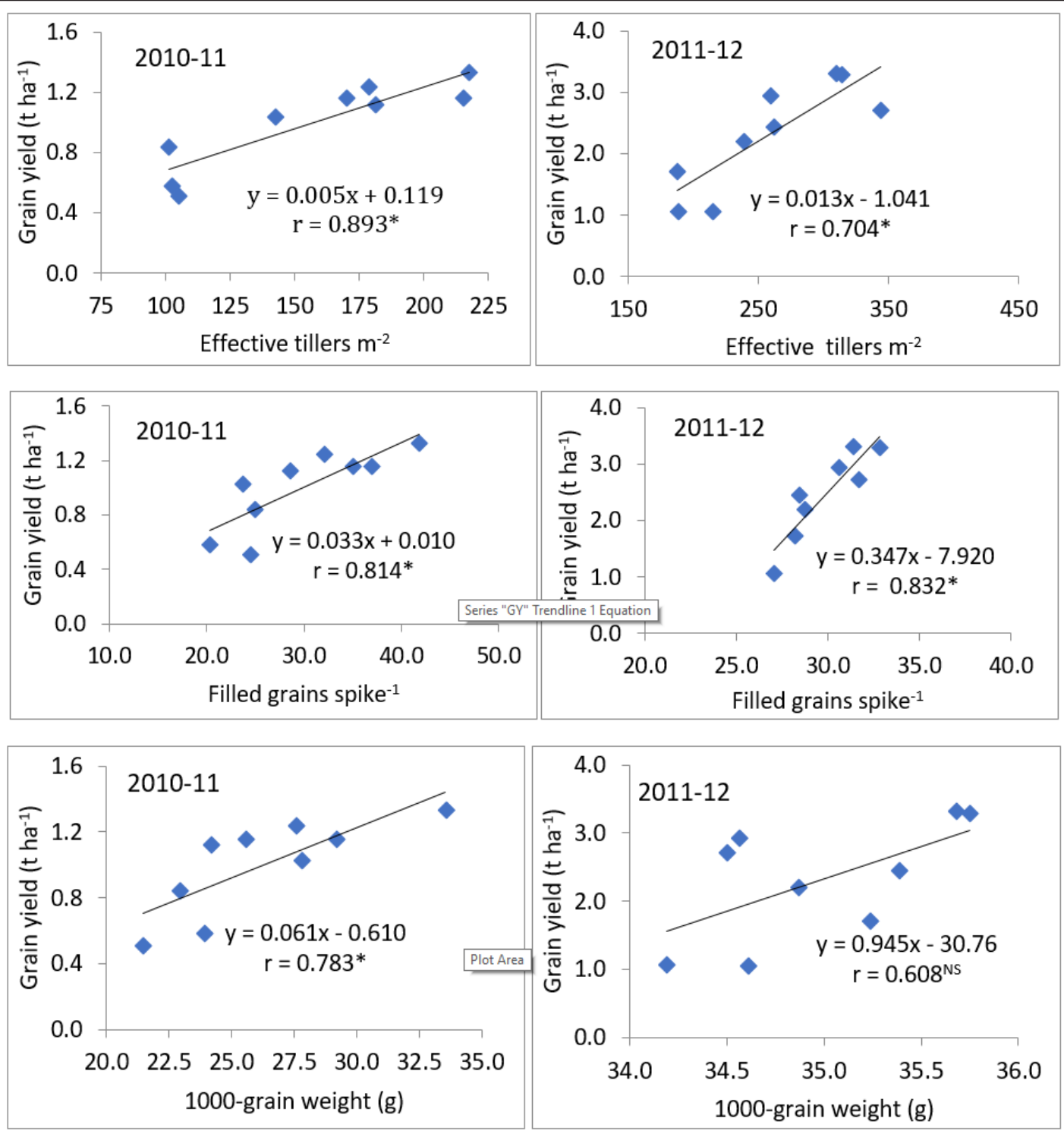

Figure 2: Regression and correlation of wheat yield $(\mathrm{y})$ with yield attributes $(\mathrm{x})$.

\section{Yield performance}

Grain, straw and biological yields of wheat showed significant variation due to preceding crops and residue management practices (Figure 3). Preceding greengram recorded higher grain, straw and biological yield of wheat in 2011-12. Crop residue having high C:N ratio took more time to decompose, which in the first season, could not add much to soil fertility. However, it helped positively in absorbing more amounts of moisture and nutrients in the second year. Leucaena twigs, on the other hand, showed significant grain yield over no residue, and that might be due to the addition of $\mathrm{N}$ through Leucaena twigs. Rapid decomposition of Leucaena twigs helped in easy availability of nutrients, which increased the growth and yield attributes leading to higher grain yield. 

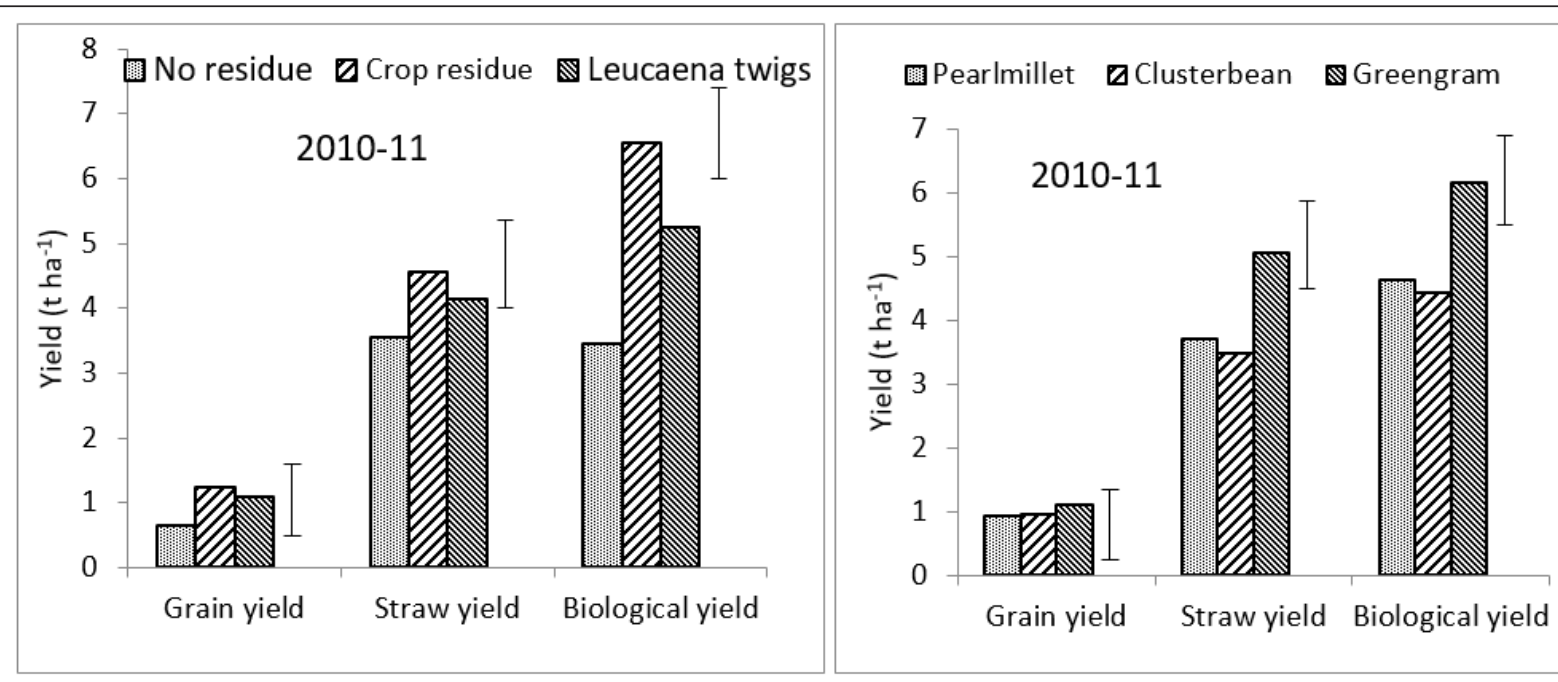

$\square$ No residue $\square$ Crop residue $\mathbb{\mathbb { Q }}$ Leucaena twigs

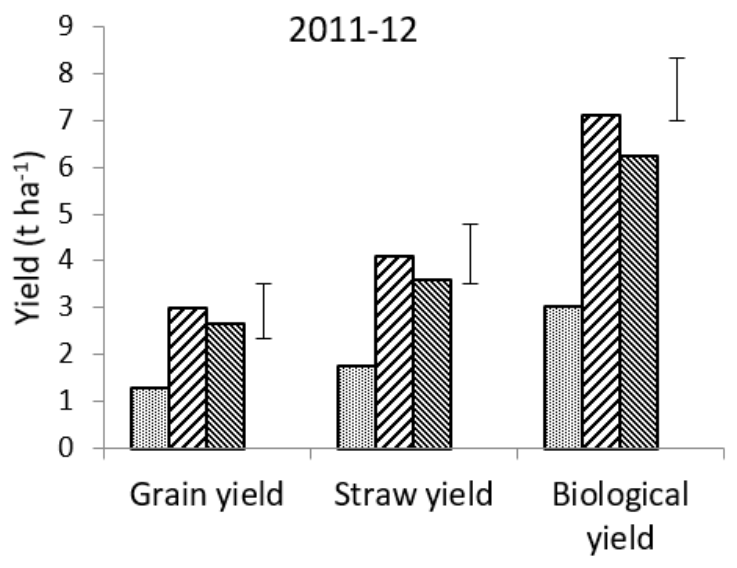

田Pearlmillet $\boldsymbol{\square}$ Clusterbean $\mathbb{Q}$ Greengram

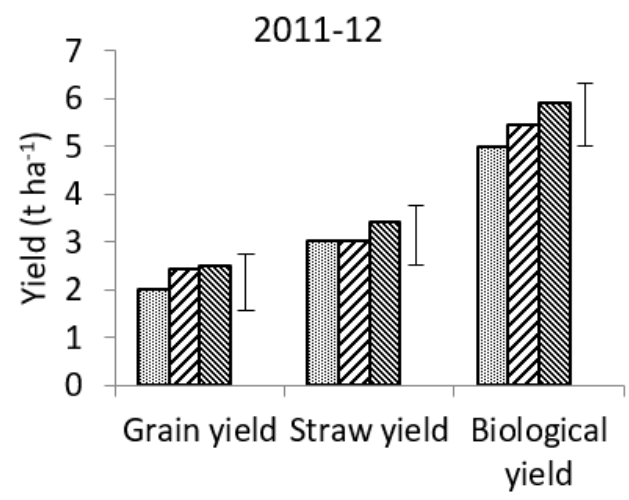

Figure 3: Yield performance of wheat as influenced by residue management and preceding rainy-season crops.

Preceding greengram along with crop residue recorded significantly higher grain yield ( $\left.3.32 \mathrm{t} \mathrm{ha}^{-1}\right)$, followed by clusterbean both with Leucaena twigs (3.29 tha $^{-1}$ ), and with crop residue (2.94 t $\mathrm{ha}^{-1}$ ) in 2011-12. However, these values remained non-significant in 2010-11. In 2011-12, retention of crop residue showed significantly superior grain yield over no residue and Leucaena twigs. These variations could be attributed to higher availability of nutrients and soil moisture provided by crop residue application. Crop residue resulted in conservation of soil moisture, and this resulted in higher yield over control and Leucaena twigs mulching. Clusterbean-wheat system produced the highest yield at Hisar [18]. and maximum water-use efficiency at Gwalior (Singh et al. (1998)). However, greengram-wheat and pearlmillet-wheat cropping systems were found suitable in Rajasthan [19,20].

Pooled analysis of grain yield of wheat as affected by year, preceding crops and residue management practices are presented in (Table 3).

\begin{tabular}{|c|c|c|c|c|c|c|c|c|c|}
\hline \multirow{2}{*}{$\begin{array}{l}\text { Preceding } \\
\text { crops }\end{array}$} & \multicolumn{4}{|c|}{ 2010-11 } & \multicolumn{4}{|c|}{ 2011-12 } & \multirow{2}{*}{$\begin{array}{c}\text { Overall } \\
\text { mean }\end{array}$} \\
\hline & NR & CR & LR & Mean & NR & CR & LR & Mean & \\
\hline Pearlmillet & 0.51 & 1.16 & 1.12 & 0.93 & 1.07 & 2.71 & 2.2 & 1.99 & 1.46 \\
\hline Clusterbean & 0.58 & 1.24 & 1.03 & 0.95 & 1.06 & 2.94 & 3.3 & 2.43 & 1.69 \\
\hline Greengram & 0.84 & 1.33 & 1.16 & 1.11 & 1.72 & 3.32 & 2.44 & 2.49 & 1.8 \\
\hline Mean & 0.64 & 1.24 & 1.1 & & 1.28 & 2.99 & 2.65 & & \\
\hline
\end{tabular}




\begin{tabular}{|c|c|c|c|c|c|c|c|}
\hline & Year (A) & Preceding crop (B) & & $A \times B$ & $A \times C$ & B $\times$ C & $A \times B \times C$ \\
\hline $\operatorname{SEm} \pm$ & 0.039 & 0.048 & 0.048 & 0.068 & 0.068 & 0.084 & 0.118 \\
\hline $\mathrm{CD}(\mathrm{P}=0.05)$ & 0.08 & 0.098 & 0.098 & 0.139 & 0.139 & 0.17 & 0.24 \\
\hline
\end{tabular}

Although there was less rainfall in the second year, the grain yield was $103 \%$ higher (2.03 tha-1) than in the first year (1.0 $\left.\mathrm{t} \mathrm{ha}^{-1}\right)$. In 2011-12, the rainfall of $14 \mathrm{~mm}$ occurred in the first and second week of January, and $20 \mathrm{~mm}$ on $13 \mathrm{March}, 2012$ remained beneficial to growth, development and grain-filling over the uniform plant population of wheat planted in November 11, 2011. Application of residue added more opportunity time for infiltration of rainfall perceived and minimized the rate of evaporation. Controlling evaporation by use of crop residue and increase in fertility status due to decomposition of residue applied in previous season crops helped to maintain stable yield over the Leucaena twigs and noresidue.

\section{Nutrient uptake}

Table 4: Effect of crop residue and Leucaena twigs on nutrient uptake $\left(\mathrm{kg} \mathrm{ha}^{-1}\right)$ in wheat after rainy-season crops in $2010-11$.

\begin{tabular}{|c|c|c|c|c|c|c|c|c|c|}
\hline \multirow{2}{*}{ Treatment } & \multicolumn{2}{|c|}{$\mathbf{N}$} & \multirow{2}{*}{ Total } & \multicolumn{2}{|c|}{$\mathbf{P}$} & \multirow{2}{*}{ Total } & \multicolumn{2}{|c|}{$\mathbf{K}$} & \multirow{2}{*}{ Total } \\
\hline & Grain & Straw & & Grain & Straw & & Grain & Straw & \\
\hline \multicolumn{10}{|c|}{ Preceding crops $(\mathrm{A})$} \\
\hline Pearlmillet (PM) & 13.7 & 14.9 & 28.6 & 2.69 & 3.61 & 6.3 & 3.84 & 51 & 54.8 \\
\hline Clusterbean (CB) & 14 & 14.4 & 28.4 & 3.15 & 3.55 & 6.7 & 3.71 & 47.1 & 50.8 \\
\hline Greengram (GG) & 16.1 & 20.9 & 37 & 3.67 & 4.99 & 8.66 & 4.1 & 67.9 & 72 \\
\hline $\mathrm{SEm}+$ & 0.51 & 0.68 & 0.84 & 0.13 & 0.14 & 0.17 & 0.14 & 1.74 & 1.78 \\
\hline $\mathrm{CD}(\mathrm{P}=0.05)$ & 1.49 & 1.99 & 2.47 & 0.38 & 0.41 & 0.49 & NS & 5.08 & 5.2 \\
\hline \multicolumn{10}{|c|}{ Residue management (B) } \\
\hline No residue (NR) & 9.7 & 11.6 & 21.3 & 2.07 & 2.95 & 5.02 & 2.52 & 38 & 40.6 \\
\hline Crop residue (CR) & 18.3 & 21.7 & 39.9 & 3.87 & 5 & 8.87 & 4.86 & 71.6 & 76.5 \\
\hline $\begin{array}{l}\text { Leucaena twigs } \\
\text { (LT) }\end{array}$ & 15.9 & 16.9 & 32.8 & 3.57 & 4.2 & 7.77 & 4.27 & 56.3 & 60.5 \\
\hline SEm + & 0.51 & 0.68 & 0.84 & 0.13 & 0.14 & 0.17 & 0.14 & 1.74 & 1.78 \\
\hline $\mathrm{CD}(\mathrm{P}=0.05)$ & 1.49 & 1.99 & 2.47 & 0.38 & 0.41 & 0.49 & 0.4 & 5.08 & 5.2 \\
\hline \multicolumn{10}{|c|}{ Interaction (A x B) } \\
\hline PM- NR & 8 & 10.6 & 18.6 & 1.51 & 2.67 & 4.17 & 2.08 & 36 & 38 \\
\hline PM - CR & 17.04 & 18.2 & 35.2 & 3.28 & 4.17 & 7.45 & 4.86 & 62.4 & 67.2 \\
\hline PM - LT & 16.06 & 15.9 & 32 & 3.3 & 3.99 & 7.29 & 4.6 & 54.5 & 59.1 \\
\hline $\mathrm{CB}-\mathrm{NR}$ & 8.59 & 9 & 17.6 & 1.91 & 2.29 & 4.19 & 2.31 & 29 & 31.3 \\
\hline CB - CR & 18.23 & 18.3 & 36.5 & 4.05 & 4.26 & 8.3 & 4.86 & 59.2 & 64.1 \\
\hline CB - LT & 15.12 & 16.1 & 31.2 & 3.48 & 4.11 & 7.59 & 3.94 & 53.1 & 57 \\
\hline GG - NR & 12.39 & 15.4 & 27.7 & 2.79 & 3.89 & 6.68 & 3.18 & 49.2 & 52.4 \\
\hline GG - CR & 19.52 & 28.6 & 48.1 & 4.29 & 6.58 & 10.87 & 4.85 & 93.3 & 98.2 \\
\hline GG - LT & 16.44 & 18.7 & 35.2 & 3.92 & 4.5 & 8.43 & 4.28 & 61.2 & 65.5 \\
\hline $\mathrm{SEm}+$ & 0.88 & 1.18 & 1.46 & 0.22 & 0.24 & 0.29 & 0.24 & 3.02 & 3.09 \\
\hline $\mathrm{CD}(\mathrm{P}=0.05)$ & NS & 3.45 & 4.27 & NS & 0.71 & 0.85 & 0.7 & 8.8 & 9.01 \\
\hline
\end{tabular}

Data on nutrient uptake by wheat are shown in (Table 4 \& 5). In general, the pattern of grain yield and straw yield was followed in total nutrient uptake as well. The rainy-season crops showed significant variation in $\mathrm{N}, \mathrm{P}$ and $\mathrm{K}$ uptake by wheat grain and straw. Greengram resulted in significantly higher grain and straw yield, and hence the nutrient uptake due to the better crop performance with crop residue retention. Similarly, crop residue management also showed significant variation in nutrient uptake with the maximum uptake under crop residue treatment. The magnitude of total nutrient uptake by wheat in 2011-12 was about 50\% more than in 2010-11 due to its higher productivity. Interaction revealed that the highest values for $\mathrm{N}$ and $\mathrm{P}$ uptake in grain after greengram and clusterbean and $\mathrm{K}$ uptake after pearlmillet as preceding crops. Significantly higher nutrient uptake with crop residue and Lecuaena twigs was due to higher growth parameters, resulting in better and higher yield over the control. 


\begin{tabular}{|c|c|c|c|c|c|c|c|c|c|}
\hline \multirow[t]{2}{*}{ Treatment } & \multicolumn{3}{|c|}{$\mathbf{N}$} & \multicolumn{3}{|c|}{$\mathbf{P}$} & \multicolumn{3}{|c|}{$\mathbf{K}$} \\
\hline & Grain & Stover & Total & Grain & Stover & Total & Grain & Stover & Total \\
\hline Preceding crops (A) & 30.7 & 12.8 & 43.5 & 6.24 & 3.06 & 9.31 & 8.83 & 42.7 & 51.6 \\
\hline Pearlmillet (PM) & 36.9 & 13.1 & 50.1 & 8.63 & 3.15 & 11.79 & 10.07 & 42.4 & 52.5 \\
\hline Clusterbean (CB) & 37.8 & 14.9 & 52.7 & 9.2 & 3.54 & 12.73 & 10.44 & 47.6 & 58 \\
\hline Greengram (GG) & 0.96 & 0.4 & 1.02 & 0.25 & 0.11 & 0.28 & 0.4 & 1.44 & 1.55 \\
\hline SEm + & 2.8 & 1.17 & 298 & 0.74 & 0.33 & 0.82 & 1.17 & 4.19 & 4.53 \\
\hline \multicolumn{10}{|c|}{$\mathrm{CD}(\mathrm{P}=\mathbf{0 . 0 5})$} \\
\hline $\begin{array}{l}\text { Residue management } \\
\text { (B) }\end{array}$ & 19.7 & 7.7 & 27.3 & 4.59 & 1.85 & 6.44 & 5.57 & 24.5 & 30.1 \\
\hline No residue (NR) & 45.4 & 17.6 & 63 & 10.21 & 4.18 & 14.39 & 12.62 & 57.6 & 70.3 \\
\hline Crop residue (CR) & 40.3 & 15.5 & 55.8 & 9.28 & 3.73 & 13 & 11.16 & 50.6 & 61.7 \\
\hline Leucaena twigs (LT) & 0.96 & 0.4 & 1.02 & 0.25 & 0.11 & 0.28 & 0.4 & 1.44 & 1.55 \\
\hline SEm + & 2.8 & 1.17 & 298 & 0.74 & 0.33 & 0.82 & 1.17 & 4.19 & 4.53 \\
\hline \multicolumn{10}{|c|}{$\mathrm{CD}(\mathrm{P}=0.05)$} \\
\hline Interaction $(\mathrm{A} \times \mathrm{B})$ & 16.6 & 5.8 & 22.3 & 3.46 & 1.39 & 4.85 & 4.88 & 18.9 & 23.8 \\
\hline PM- NR & 41.6 & 17.7 & 59.3 & 8.25 & 4.23 & 12.48 & 11.77 & 59.7 & 71.5 \\
\hline PM - CR & 33.9 & 14.9 & 48.8 & 7.02 & 3.57 & 10.59 & 9.84 & 49.5 & 59.4 \\
\hline PM - LT & 16.2 & 7 & 23.2 & 3.7 & 1.69 & 5.38 & 4.5 & 22 & 26.5 \\
\hline CB - NR & 44.5 & 14.9 & 59.3 & 10.27 & 3.5 & 13.77 & 12.28 & 48.2 & 60.5 \\
\hline $\mathrm{CB}-\mathrm{CR}$ & 50.1 & 17.6 & 67.7 & 11.93 & 4.28 & 16.21 & 13.44 & 57.1 & 70.5 \\
\hline CB - LT & 26.3 & 10.2 & 36.5 & 6.6 & 2.46 & 9.07 & 7.33 & 32.6 & 39.9 \\
\hline GG - NR & 50.2 & 20.3 & 70.5 & 12.1 & 4.81 & 16.91 & 13.8 & 65 & 78.8 \\
\hline GG - CR & 36.8 & 14.2 & 51 & 8.88 & 3.34 & 12.22 & 10.19 & 45.1 & 55.3 \\
\hline GG - LT & 1.66 & 0.7 & 1.77 & 0.44 & 0.2 & 0.49 & 0.7 & 2.49 & 2.69 \\
\hline SEm + & 4.85 & 2.03 & 5.16 & 1.28 & 0.57 & 1.43 & 2.03 & 7.26 & 7.85 \\
\hline
\end{tabular}

There was poor crop growth in no-residue treatment; and therefore, nutrient uptake was also less in control than with residue application. The increased uptake of NPK under residue application was attributed to higher yield because of availability of moisture to the plants. The overall improvement in growth of wheat due to residual effect of crop residue applied to previous legumes like greengram and clusterbean, and with Leucaena twigs could be ascribed to their pivotal role in several physiological and biochemical processes, viz. root development, photosynthesis, energy transformation (ATP and ADP) and symbiotic biological $\mathrm{N}_{2}$ fixation processes and in protein synthesis $[3,16,21]$.

\section{Economics}

The perusal of data on economic performance of wheat as influenced by preceding rainy-season crops and residue management suggested that cost of cultivation was relatively high in 2011-12 than 2010-11, but the net returns were almost half in 2010-11 compared with 2011-12 (Table 6). The increase in production cost in 2011-12 was due to higher labour wages by $33 \%$ and other input costs. There was higher yield in 2011-12 and value of output was also high, resulting in 50\% more net returns. The crop residues have economic value, and their market prices were added to the production cost. Leucaena twigs were freely available and only application costs were incurred. The economic analysis exhibited the highest returns and net returns/ invested under greengram with crop residue, followed by clusterbean with Leucaena twigs. Clusterbean with crop residue and Leucaena twigs and greengram with crop residue, all other treatments recorded negative net returns in 2010-11. Singh et al. [16], Saxena et al. [18], Singh et al. [20] reported the highest net returns under greengram-wheat, clusterbean-wheat and clusterbean-mustard systems with organic residue and other treatment combinations. This indicated that wheat after greengram and clusterbean along with crop residue and Leucaena twigs mulching was high-yielding and profitable cropping system under zero-till semi-arid condition. 
Table 6: Effect of crop residue and Leucaena twigs on economics of wheat after different rainy-season crops.

\begin{tabular}{|c|c|c|c|c|c|c|c|c|}
\hline \multirow{3}{*}{ Treatment } & \multirow{2}{*}{\multicolumn{2}{|c|}{$\begin{array}{c}\text { Cost of cultivation } \\
\left(\mathrm{x}^{\prime 03}{ }^{`} \mathrm{ha}^{-1}\right)\end{array}$}} & \multirow{2}{*}{\multicolumn{2}{|c|}{$\begin{array}{c}\text { Gross returns } \\
\left(\text { x103 }^{`} \mathrm{ha}^{-1}\right)\end{array}$}} & \multirow{2}{*}{\multicolumn{2}{|c|}{$\begin{array}{l}\text { Net returns } \\
\left(\mathrm{x}^{\prime 03}{ }^{`} \mathrm{ha}^{-1}\right)\end{array}$}} & \multirow{2}{*}{\multicolumn{2}{|c|}{ Net returns/ invested }} \\
\hline & & & & & & & & \\
\hline & $2010-11$ & $2011-12$ & $2010-11$ & $2011-12$ & $2010-11$ & $2011-12$ & $2010-11$ & $2011-12$ \\
\hline Pearlmillet - no residue & 11.61 & 15.79 & 6.51 & 14.55 & -5.1 & -1.25 & -0.44 & -0.08 \\
\hline Pearlmillet - crop residue & 14.06 & 18.89 & 14.11 & 37.34 & 0.05 & 18.45 & 0 & 0.98 \\
\hline Pearlmillet - Leucaena twigs & 13.11 & 17.79 & 13.37 & 30.37 & 0.27 & 12.58 & 0.02 & 0.71 \\
\hline Clusterbean - no residue & 11.61 & 15.79 & 6.98 & 14.57 & -4.63 & -1.23 & -0.4 & -0.08 \\
\hline Clusterbean - crop residue & 14.06 & 18.89 & 14.84 & 39.84 & 0.79 & 20.94 & 0.06 & 1.11 \\
\hline Clusterbean - Leucaena twigs & 13.11 & 17.79 & 12.47 & 44.71 & -0.64 & 26.92 & -0.05 & 1.51 \\
\hline Greengram - no residue & 11.61 & 15.79 & 10.4 & 23.49 & -1.21 & 7.7 & -0.1 & 0.49 \\
\hline Greengram - crop residue & 14.06 & 18.89 & 17.07 & 45.49 & 3.01 & 26.59 & 0.21 & 1.41 \\
\hline Greengram - Leucaena twigs & 13.11 & 17.79 & 14.09 & 33.29 & 0.99 & 15.5 & 0.08 & 0.87 \\
\hline
\end{tabular}

\section{Conclusion}

It was concluded that growth parameters, yield attributes, yield, nutrient uptake and economics of wheat was significantly influenced by preceding rainy-season crops and residue retention. Crop residue retention followed by Leucaena twigs was found to be significantly better than no-residue. It was recommended to adopt greengram-wheat and clusterbean-wheat cropping systems with crop residue or Leucaena twigs under zero-till semi-arid condition.

\section{References}

1. Anonymous (2010) Package of practices for Rabi crops. Punjab Agricultural University, Ludhina, Punjab, India.

2. Saxena, M.C. (2012) Challenges and opportunities for food legume research and development. Paper presented on the 6th M.S. Swaminathan Award Lecture at IARI, Pusa, New Delhi, India.

3. Ali Masood, Ganeshsmurthy AN, Srinivasan Rao Ch (2002) Role of pulses in soil health and sustainable crop production. Indian Journal of Pulse Research 15 (2): 107-117.

4. Vaidya VB, Varshneya MC, Bote NL, Naidu JRV (1995) Estimation of thermal efficiency and apparent reflectivity of mulches using soil temperature. Journal of Maharashtra Agricultural Universities 20(3): 341-344.

5. Acharya CL, Kapur OC, Dixit SP (1998) Moisture conservation for rainfed wheat production with alternative mulches and conservation tillage in hills of north-west India. Soil and Tillage Research 46(3-4): 153-163.

6. Sharma PK, Acharya CL (2000) Carry-over of residual soil moisture with mulching and conservation tillage practices for sowing of rainfed wheat (Triticum aestivum) in north-west India. Soil and Tillage Research 57(12): 43-52.

7. Sharma AR, Singh R, Dhyani SK, Dube RK (2010) Moisture conservation and nitrogen recycling through legume mulching in rainfed maize (Zea mays)-wheat (Triticum aestivum) cropping system. Nutrient Cycling in Agroecosystems 87(2): 187-197.

8. Sharma AR, Singh R, Dhyani SK, Dube RK (2011) Agronomic and economic evaluation of mulching on rainfed-maize-wheat cropping system on the western himalayan region of India. Journal of Crop Improvement 25 (4): 392-408.

9. Sharma AR, Behera UK (2009) Nitrogen contribution through Sesbania green manure and dual-purpose legumes in maize-wheat cropping system: agronomic and economic considerations. Plant and Soil 325(12): 289-304.
10. Jones RB, Wendt JW, Bunderson WT, Itimu OA (1996). Leucaena-maize alley cropping in Malawi. Part I: Effects of N, P and leaf application on maize yields and soil properties. Agroforestry Systems 33 (3): 281-294.

11. Lehria SK, Bali SV, Singh B (2006). Effect of green leaf manure of subabul (Leucaena leucocphala Lam. De Wit.) on maize crop and its residual effect on wheat crop. In: Verma KS et al. (Eds.) Proceedings of the IUFROS-ISTS l-UHF International Conference on World Perspective on Short-rotation Forestry for Industrial and Rural Development. Solan, India. pp. 316-319.

12. Jat ML, Gathala MK, Ladha JK, Saharawat YS, AS Jat, et al (2009) Evaluation of precision land leveling and double zero-till systems in the rice-wheat rotation: Water use, productivity, profitability and soil physical properties. Soil and Tillage Research 105: 112-121.

13. Prasad, R., Shivay YS, Kumar D, Sharma SN (2006) Learning by Doing Exercises in soil Fertility - A Practical Manual for Soil Fertility, pp. 1-68. Division of Agronomy, Indian Agricultural Research Institute, New Delhi, India.

14. Gomez KA, Gomez AA (1984) Statistical Procedures for Agricultural Research. John Willley and Sons, NY, India.

15. Rathore AL, Pal AR, Sahu KK (1998) Tillage and mulching effects on water use, root growth and yield of rainfed mustard and chickpea grown after lowland rice. Journal of the Science of Food and Agriculture 78(2): $149-161$.

16. Singh BP, Mundra MC, Gupta GC (2003) Productivity, stability and economics of various cropping systems in semi-arid ecosystem. Crop Research (Hisar) 25(3): 472-477.

17. Jain NK, Besarwal HS, Dashora LN (2011) Production potential, profitability, sustainability and energetics of different wheat (Triticum aestivum)-based cropping systems. Archives of Agronomy and Soil Science 57(5): 477-487.

18. Saxena A, Singh DV, Joshi NL (1997) Effects of tillage and cropping systems on soil moisture balance and pearlmillet yield. Journal Agronomy and Crop Science 178: 251-257.

19. Lal M, Bhati DS, Nag AK (2004) Economics and production potential of different cropping sequence on farmers' field. Journal of Eco-Physiology 7(3-4): 143-145.

20. Singh R, Singh B, Patidar M (2008) Effect of preceding crops and nutrient maangemetn on productivity of wheat (Triticum aestivum)-based cropping system in arid region. Indian Journal of Agronomy 53 (4): $267-$ 272.

21. Tisdale SL, Nelson WL, Beaton JT, Havlin JL (1995) Soil Fertility and Fertilizers, $\left(5^{\text {th }}\right.$ edn), Prentice Hall of India Pvt. Ltd., New Delhi. p. 62-75.

22. Saxena A, Singh YV, Singh R (2004) Crop-weed competition in clusterbean in arid region. Journal of Arid Legumes 1(1): 41-43. 